\title{
Zinc Finger E-Box-Binding Homeobox 2
}

National Cancer Institute

\section{Source}

National Cancer Institute. Zinc Finger E-Box-Binding Homeobox 2. NCI Thesaurus. Code C75443.

Zinc finger E-box-binding homeobox $2(1214 \mathrm{aa}, \sim 136 \mathrm{kDa})$ is encoded by the human ZEB2 gene. This protein is involved in the negative regulation of transcription. 